EKONOMIKAWAN : Jurnal Ilmu Ekonomi dan Studi Pembangunan

ISSN : $1693-7600$ (Print), ISSN : 2598-0157 (Online), http://jurnal.umsu.ac.ld/index.php/ekawan

\title{
Analisis Penentuan Sektor Unggulan Perekonomian dan Formulasi Strategi Pengembangannnya di Kabupaten Indragiri Hilir
}

\author{
Syapsan \\ Fakultas Ekonomi Universitas Riau \\ Kampus Bina Widya Km. 12.5, Simpang Baru, Kec.Tampan, Kota Pekanbaru, Riau 28292 \\ e-mail : syapsan@yahoo.com
}

\begin{abstract}
ABSTRAK
Indonesia memiliki tujuan untuk menyejahterakan kehidupan masyarakat secara menyeluruh melalui pembangunan nasional. Penelitian ini bertujuan memperkuat daya saing sehingga dapat mendorong pertumbuhan ekonomi dengan cara mengetahui sektor ekonomi di Kabupaten Indragiri Hilir. Data yang digunakan adalah data primer dan sekunder periode tahun 2012-2016 berupa kuesioner dan PDRB Kabupaten Indragiri. Metode analisis yang digunakan adalah Location Quotient (LQ), Shift Share (SS), Model Rasio Pertumbuhan (MRP), Analitycal Hierarchy Process (AHP). Hasil penelitian ini memperoleh hasil jika sektor ekonomi pertama yaitu pertanian berperan sebagai sektor basis yang memiliki keunggulan kompetitif. Penelitian menggunakan alat analisis AHP menghasilkan bahwa strategi perencanaan pembangunan untuk Kabupaten Indragiri Hilir dalam pengembangan sektor unggulan adalah dengan kebijakan promosi daerah yang didukung melalui masterplan daerah dan pemasaran daerah.
\end{abstract}

Kata Kunci: Keunggulan Kompetitif, Pertumbuhan Ekonomi dan Kontribusi Ekonomi, PDRB, Sektor Basis, Strategi Perencanaan Pembangunan 


\title{
Analysis of Determination of Economic Leading Sectors and Formulation of Development Strategies in Indragiri Hilir Regency
}

\begin{abstract}
Indonesia has a purpose to fully enrich society's life through national development. This research aims to strengthen competitiveness so as to encourage economic growth by knowing the economic sector in Indragiri Hilir district. The data used is the primary and secondary data period of 2012-2016 in the form of questionnaires and PDRB of Indragiri district. The methods of analysis used are Location Quotient (LQ), Shift Share (SS), growth ratio Model (MRP), analyitycal Hierarchy Process (AHP). The results of this study gained results if the first economic sector, namely agriculture, serves as a base sector that has a competitive advantage. Research using the AHP analysis tool resulted that the development planning strategy for the district of Indragiri Hilir in the development of the superior sector is with the policy of regional promotion supported through regional Macerplan and marketing Area.
\end{abstract}

Keywords: Competitive Advantages, Economic Growth and Economic

Contribution, Gross Regional Domestic Product, Leading Sectors, Strategy Development Planning

\section{PENDAHULUAN}

Pembangunan daerah adalah pembangunan yang bertujuan untuk menyejahterakan masyarakat dengan membangun daerah. Potensi daerah yang berbeda menyebabkan pelaksanaan pembangunan tidak dapat disamaratakan. Proses pembangunan ini erat kaitanny adengan proses desentralisasi pembangunan, sebagaimana tertuang dalam UU RI No.32 Tahun 2004 tentang Pemerintah Daerah (Kuncoro, 2004).

UU RI No. 32 Tahun 2004 tentang Pemerintah Daerah membuka peluang bagi daerah dalam memanfaatkan sumber daya alam dan manusia yang memiliki kualitas dan berpotensi sehingga mampu menangkap peluang dengan cermat dan mampu berinisiatif dalam menemukan segala potensi yang ada di daerahnya, untuk secara optimal dikembangkan guna kesejahteraan wilayahnya. Sumber daya manusia yang berkualitas dengan cepat mampu meminimalisir segala hambatan yang ada dalam upaya peningkatan kesejahteraan wilayahnya (Jerri, 2012).

Kabupaten Indragiri memiliki wewenang untuk mengambil keputusan berbagai kebijakan yang dapat dinikmati oleh seluruh masyarakat dengan memanfaatkan potensi daerah. Potensi ekonomi tersebut dapat dilihat dari trend pertumbuhan ekonorni daerah. Lebih lanjut terkait dengan pertumbuhan ekonomi daerah dapat dilihat pada gambar dibawah. 
Published July 2019

EKONOMIKAWAN : Jurnal Ilmu Ekonomi dan Studi Pembangunan

ISSN : 1693-7600 (Print), ISSN : 2598-0157 (Online), http://jurnal.umsu.ac.Id/index.php/ekawan

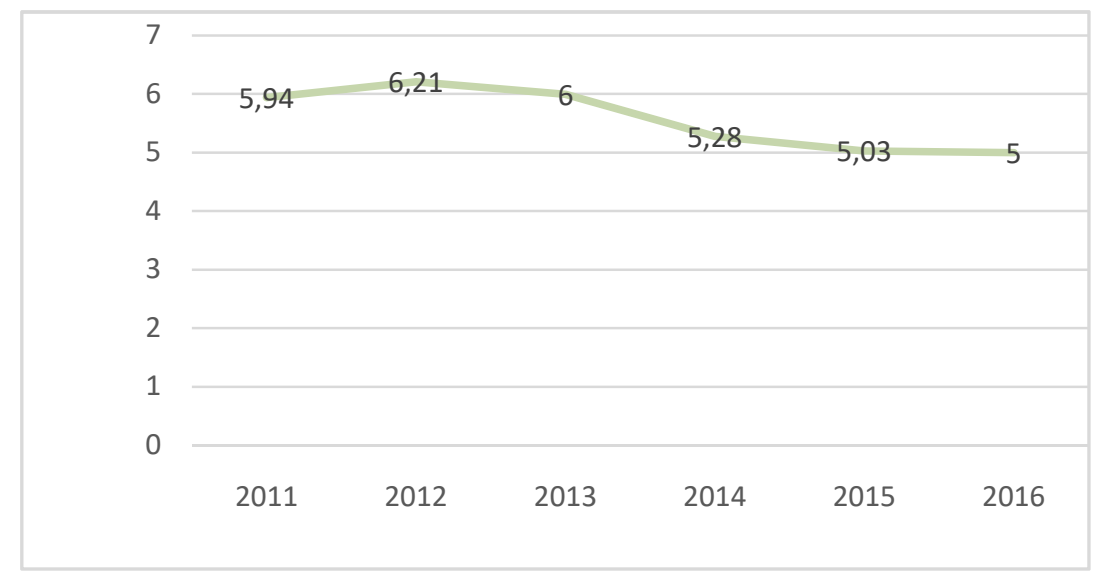

Gambar 1. Laju Pertumbuhan Ekonomi Kabupaten Indragiri Hilir 6 Tahun Terakhir (Sumber: BPS Kabupaten Indragiri 6 Tahun Terakhir)

Berdasarkan gambar 1 laju pertumbuhan ekonomi tahun 2012 naik 0,27\%. Tahun 2013-2016 mengalami penurunan dengan masing-masing 6,00\%; 5,28\%; 5,03\%; 5.00\%. Sektor pertanian masih mendominasi dalam pembentukan PDRB yaitu sebesar 27\%, dikarenakan luas areal sawah sebesar $12.816 \mathrm{Ha}$, tanah kering $38.858 \mathrm{Ha}$, dan perkebunan $2.536 \mathrm{Ha}$, (lihat tabel 2) menghasilkan padi sawah dan ladang sebesar 210.924 ton padi, 98.668 ton jagung, 205.563 ton kayu serta komoditi pertanian lainnya (lihat tabel 3). Selain itu, disusul lapangan usaha ketujuh yaitu perdagangan besar dan eceran sebesar 17\%, lapangan usaha ketiga yaitu industri pengolahan $14 \%$, sedangkan lapangan usaha lainnya kurang dari $10 \%$.

Peran pemerintah daerah diperlukan untuk membuat strategi dan perencanaan pembangunan daerah guna meningkatkan pertumbuhan ekonomi daerah dengan melihat pergeseran sektor ekonomi setiap tahunnya (Taufik, 2012) sehingga pemerintah daerah perlu mengetahui pengaruh yang merubah pertumbuhan ekonomi daerah itu sendiri.

Lestari (2017) menjelaskan bahwa peranan lapangan usaha berpengaruh signifikan pada PAD kabupaten Sarolangun sehingga dapat disimpulkan bahwa sektor basis memiliki peranan sangat penting terhadap perekonomian daerah.

Berdasarkan keadaan kabupaten Indragiri Hilir yang telah diuraikan, terdapat beberapa sektor ekonomi yang memiliki keunggulan kompetitif maupun komparatif yang perlu menjadi perhatian bagi pemerintah yaitu lapangan usaha pertama pertanian yang berkontribusi paling besar diperkuat dengan luasnya lahan yang dijadikan sebagai lahan pertanian maupun perkebunan. Selain itu disusul dengan sektor perdagangan dan eceran, serta industri pengolahan yang banyak berdiri di kabupaten Indragiri Hilir khususnya industri anyaman bambu/tikar (BPS Kabupaten Indragiri Hilir, 2017).

Pertumbuhan ekonomi suatu daerah akan lebih efisien dalam melakukan kegiatan ekonomi sehingga dapat dialokasikan pada perdagangan jika daerah tersebut memiliki sumber daya yang memiliki keunggulan absolut dan komparatif. Perencanaan pembangunan dalam rangka peningkatan pertumbuhan ekonomi membutuhkan identifikasi sektor ekonomi atau lapangan usaha berpotensi sehingga dapat dipermudah (Sirojuzilam, 2008:3). 
Published July 2019

EKONOMIKAWAN : Jurnal Ilmu Ekonomi dan Studi Pembangunan

ISSN : 1693-7600 (Print), ISSN : 2598-0157 (Online), http://jurnal.umsu.ac.Id/index.php/ekawan

Terkait dengan latar belakang masalah tersebut maka paper ini membuat formulasi pertanyaan yaitu: (1) Sektor apa yang memiliki potensi sebagai sektor basis serta memiliki keunggulan kompetitif atau daya saing dan spesifikasi dan (2) Bagaimana strategi pengembangan sektor unggulan dan non unggulan untuk pembangunan wilayah.

\section{KAJIAN TEORI}

\section{Teori Lokasi}

Teori lokasi berlandaskan pada pengoptimalan pemanfaatan ruang yang menggambarkan posisi kegiatan ekonomi. Kegiatan ini memiliki jarak lokasi yang menimbulkan konsekuensi seperti munculnya biaya transportasi angkutan. Teori lokasi berprinsip bahwa pemanfaatan optimal dapat dilakukan apabila memperkirakan kembali pemilihan lokasi yang cocok untuk kegiatan ekonomi dalam suatu tempat.

Menurut Weber, lokasi industri dipilih berdasarkan pada prinsip meminimalisasikan biaya transportasi dan tenaga kerja yang dipengaruhi aglomerasi atau deglomerasi sehingga mendapatkan keuntungan paling besar. Keterkaitan antara biaya transportasi dan bahan baku dapat dijelaskan dengan menggunakan konsep segitiga lokasi untuk menetapkan lokasi ekonomi.

\section{Daya Saing Daerah}

Menurut Departemen Perdagangan dan Industri Inggris, daya saing adalah kekuatan suatu daerah dalam memperoleh penghasilan yang dapat memperluas lapangan kerja yang berhubungan pada persaingan di dalam maupun luar daerah. Menurut The European Cmmision, daya saing adalah kekuatan suatu daerah untuk menghasilkan barang ataupun jasa yang dibutuhkan oleh pasar internasional serta peningkatan pendapatan untuk menambah kas daerah sehingga permintaan terhadap tenaga kerja tetap meningkat.

Kedua penjelasan mengenai daya saing tersebut terdapat beberapa kesamaan antara daya saing daerah dan daya saing nasional yaitu:

a. Daya saing membahas mengenai kemampuan produktivitas dan efisiensi suatu perekonomian dari suatu perekonomian secara luas tidak hanya dalam ruang lingkup mikro saja.

b. Konsep daya saing mencakup pelaku ekonomi yaitu perusahaan, rumah tangga, perusahaan swasta dan masih banyak lagi.

c. Peningkatan kesejahteraan penduduk merupakan tujuan akhir dari peningkatan daya saing perekonomian.

\section{METODE}

Ketiga analisis yaitu LQ, Shift Share dan MRP yang menggunakan enam tahun periode dengan data PDRB diuraikan sebagai berikut.

\section{Analisis Location Quotient (LQ)}

Potensi utama ekonomi daerah secara sektoral ataupun komoditi dapat dicari menggunakan analisis LQ dengan menghitung apakah potensi daerah tersebut masuk dalam kategori sektor basis atau non basis. Rumus yang digunakan adalah sebagai berikut:

$$
\mathbf{L Q}=\frac{\mathrm{v} / \mathrm{v}}{\mathbf{Y} / \mathbf{Y}}
$$


Published July 2019

EKONOMIKAWAN : Jurnal Ilmu Ekonomi dan Studi Pembangunan

ISSN : $1693-7600$ (Print), ISSN : 2598-0157 (Online), http://jurnal.umsu.ac.Id/index.php/ekawan

di mana Vi merupakan nilai PDRB sektor i pada kabupaten $\mathrm{x}, \mathrm{Vt}$ adalah total PDRB kabupaten $\mathrm{x}$, Yi adalah nilai PDRB sektor i pada Provinsi $\mathrm{x}$ dan Yt adalah total PDRB Provinsi x. Jika nilai LQ $<1$, maka masuk dalam kategori sektor basis dan sebaliknya jika LQ > 1, maka sektor tersebut masuk dalam kategori sektor non basis.

\section{Analisis Shift Share}

Menurut Soepomo (Taufik, 2011) rumus yang digunakan dalam analisis ini adalah sebagai berikut:

$$
\begin{aligned}
& \mathrm{Dij}=\mathrm{Nij}+\mathrm{Mij}+\mathrm{Cij} \\
& \mathrm{Nij}=\mathrm{Yij} . \mathrm{Yn} \\
& \mathrm{Mij}=\mathrm{Yij}(\text { rin }-\mathrm{rn}) \\
& \mathrm{Cij}=\mathrm{Yij}_{\mathrm{ij}}(\mathrm{rij}-\mathrm{rin}) \\
& \mathrm{rij}=\left(\mathrm{Y}^{*} \mathrm{ij}-\mathrm{Yij}\right) / \mathrm{Yij} \\
& \mathrm{rin}=\left(\mathrm{Y}^{*} \mathrm{in}-\mathrm{Yin}\right) / \mathrm{Yin}
\end{aligned}
$$

di mana Yij merupakan PDRB sektor i di Kabupaten $\mathrm{x}$ dan Yin adalah PDRB sektor $\mathrm{i}$ di Provinsi $\mathrm{X}$.

\section{Analisis Model Rasio Pertumbuhan (MRP)}

Perbandingan perubahan pertumbuhan dari pendapatan $\mathrm{i}$ di wilayah $\mathrm{x}$ dengan perubahan total pendapatan $\mathrm{i}$ di wilayah $\mathrm{x}$ adalah analisis MRP dengan rumus sebagai berikut.

di mana

$$
\mathbf{R}=\frac{\Delta \mathbf{E} / \mathbf{E}}{\Delta \mathbf{E} / \mathbf{E}}
$$

$\Delta$ Ein $=$ perubahan pendapatan sektor $\mathrm{i}$ di wilayah $\mathrm{x}$

Ein $=$ pendpatan sektor $\mathrm{i}$ di wilayah $\mathrm{x}$ (tahun dasar)

$\Delta \mathrm{En}=$ total pendapatan di wilayah $\mathrm{x}$ (tahun dasar)

Apabila RPr lebih besar positif dari 1 maka pertumbuhan sektor i wilayah $\mathrm{x}$ lebih tinggi dari pertumbuhan total wilayah $\mathrm{x}$ dan sebaliknya jika RPr lebih kecil negatif dari 1 maka pertumbuhan tersebut lebih rendah.

\section{Analytical Hierarchy Process (AHP)}

Penentuan prioritas keputusan dari masalah yang ada dapat dipecahkan menggunakan analisis AHP. Analisis ini dapat dipecahkan dengan proses penstrukturan hirarki yang disusun berdasarkan tujuan yang diinginkan. Analisis ini menggunakan lima tahapan dengan menentukan masalah dan solusi terlebih dahulu yang dilanjutkan dengan membuat hirarki dengan tujuan diawal lalu kriteria dan subkriteria yang terkahir alternatif. Tahapan selanjutnya membuat tabel perbandingan berpasangan dari kriteria, subkriteria dan alternatif lalu dari tabel tersebut ditentukan bobot masing-masing. Tahapan akhir melakukan uji konsistensi indeks dan rasio ketidakkonsistenan.

$$
\mathbf{C}=\frac{\lambda-\mathbf{n}}{n-1}
$$


Published July 2019

EKONOMIKAWAN : Jurnal Ilmu Ekonomi dan Studi Pembangunan

ISSN : 1693-7600 (Print), ISSN : 2598-0157 (Online), http://jurnal.umsu.ac.id/index.php/ekawan

di mana Consisitency Index (CI) merupakan indeks konsistensi, $\lambda$ max merupakan nilai eign maksimal dari matriks. CI dikatakan konsisten apabila menghasilkan nilai 0 jika kurang dari 0 maka tidak konsisten.

\section{$\mathbf{C R}=\mathbf{C I} / \mathbf{R I}$}

\section{HASIL DAN PEMBAHASAN}

Penelitian dari analisis LQ menghasilkan 9 sektor yang masuk dalam kategori basis, antara lain adalah sebagai berikut:

1) Lapangan usaha Pertanian, Kehutanan dan Perikanan

2) Lapangan usaha Pertambangan dan Penggalian

3) Lapangan usaha Informasi dan Komunikasi

4) Lapangan usaha Jasa Keuangan dan Asuransi

5) Lapangan usaha Real Estate

6) Lapangan usaha Administrasi Pemerintahan, Pertahanan dan Jaminan Sosial Wajib

7) Lapangan usaha Jasa Pendidikan

8) Lapangan usaha Kesehatan dan Kegiatan Sosial

9) Lapangan usaha jasa lainnya

Kesembilan lapangan usaha yang masuk dalam kategori basis tersebut memiliki tingkat dominan lebih tinggi dari pada lapangan usaha lainnya karena memiliki keunggulan komparatif. Lapangan usaha tersebut membantu meningkatkan pertumbuhan ekonomi daerah Indragiri. Hasil olahan dari lapangan usaha tersebut diekspor ke luar daerah sehingga memperoleh pendapatan dari luar daerah.

Tabel 1. Hasil Analisis LQ Kabupaten Indragiri Tahun 2012-2016

\begin{tabular}{|c|c|c|c|c|c|c|c|}
\hline \multirow{2}{*}{\multicolumn{2}{|c|}{ Sektor Ekonomi }} & \multicolumn{5}{|c|}{ Tahun } & \multirow{2}{*}{$\begin{array}{l}\text { Rata- } \\
\text { Rata }\end{array}$} \\
\hline & & 2012 & 2013 & 2014 & 2015 & 2016 & \\
\hline 1 & Sektor pertanian, kehutanan dan perikanan & 1.2137 & 2.2438 & 2.2778 & 2.3093 & 2.3455 & 2.2789 \\
\hline 2 & Sektor pertambangan dan penggalian & 1.3475 & 1.3498 & 1.3560 & 1.3141 & 1.1969 & 1.3129 \\
\hline 3 & Sektor industri pengolahan & 0.4857 & 0.4849 & 0.4849 & 0.4898 & 0.4933 & 0.4877 \\
\hline 4 & Sektor Pengadaan listrik dan gas & 0.1282 & 0.1272 & 0.1281 & 0.1285 & 0.1329 & 0.1290 \\
\hline 5 & $\begin{array}{l}\text { Sektor pengadaan air, pengelolaan sampah, } \\
\text { limbah dan daur ulang }\end{array}$ & 0.5815 & 0.5948 & 0.6118 & 0.6126 & 0.6148 & 0.6031 \\
\hline 6 & Sektor kontruksi & 0.7948 & 0.7997 & 0.8121 & 0.8102 & 0.8145 & 0.8063 \\
\hline 7 & $\begin{array}{l}\text { Sektor perdagangan besar, eceran dan } \\
\text { reparasi mobil dan sepeda motor }\end{array}$ & 0.9146 & 0.9135 & 0.9103 & 0.9125 & 0.9175 & 0.9137 \\
\hline 8 & Sektor transportasi dan pergudangan & 0.4667 & 0.4715 & 0.4874 & 0.4904 & 0.4966 & 0.4825 \\
\hline 9 & $\begin{array}{l}\text { Sektor penyediaan akomodasi dan makan } \\
\text { minum }\end{array}$ & 0.3520 & 0.3581 & 0.3554 & 0.3557 & 0.3537 & 0.3550 \\
\hline 10 & Sektor informasi dan komunikasi & 1.0470 & 1.0649 & 1.0396 & 1.1073 & 1.1144 & 1.0854 \\
\hline 11 & Sektor jasa keuangan dan asuransi & 1.0280 & 1.0075 & 0.9999 & 0.9870 & 0.9938 & 1.0032 \\
\hline 12 & Sektor real estate & 1.2118 & 1.2133 & 1.2206 & 1.2337 & 1.2529 & 1.2244 \\
\hline 13 & Sektor jasa perusahaan & 0.3205 & 0.3153 & 0.3156 & 0.3174 & 0.3196 & 0.3177 \\
\hline 14 & $\begin{array}{l}\text { Sektor adm perusahaan, pertahanan dan } \\
\text { jaminan sosial wajib }\end{array}$ & 1.9113 & 1.9170 & 1.9351 & 1.9435 & 1.9607 & 1.9335 \\
\hline 15 & Sektor jasa pendidikan & 1.7139 & 1.7208 & 1.7329 & 1.7326 & 1.7412 & 1.7283 \\
\hline 16 & Sektor jasa kesehatan dan kegiatan sosial & 1.3438 & 1.3385 & 1.4159 & 1.3549 & 1.3657 & 1.3638 \\
\hline 17 & Sektor jasa lainnya & 1.9034 & 1.9264 & 1.9766 & 1.9826 & 1.9952 & 1.9568 \\
\hline
\end{tabular}


Published July 2019

EKONOMIKAWAN : Jurnal Ilmu Ekonomi dan Studi Pembangunan

ISSN : 1693-7600 (Print), ISSN : 2598-0157 (Online), http://jurnal.umsu.ac.Id/index.php/ekawan

\section{Hasil Analisis Shift Share}

Analisis Shift Share dipengaruhi beberapa komponen, yaitu: pertumbuhan provinsi (Nij), komponen bauran industri (Mij), keunggulan kompetitif (Cij), jumlah keseluruhan (Dij). Penelitian ini memperoleh hasil sebagai berikut:

a. Sektor Pertanian, Kehutanan dan Perikanan

Berdasarkan komponen $\mathrm{Nij}$, Cij dan Dij pertumbuhan sektor ini bertumbuh relatif lebih cepat dibandingkan dengan sektor sejenis lainnya di provinsi Riau dikarenakan komponen tersebut memberikan pengaruh positif sebesar masing-masing $\mathrm{Rp} \mathrm{320,02}$ miliar; Rp 60,70 miliar; Rp 223,42 miliar. Sedangkan berdasarkan komponen Mij pertumbuhan sektor ini bertumbuh relatif lebih lambat dibandingkan dengan sektor sejenis lainnya di provinsi Riau dikarenakan komponen tersebut memberikan pengaruh negatif sebesar Rp 157,30 miliar.

b. Sektor Pertambangan dan Penggalian

Berdasarkan komponen Nij, Mij dan Dij pertumbuhan sektor ini bertumbuh relatif lebih cepat dibandingkan dengan sektor sejenis lainnya di provinsi Riau dikarenakan komponen tersebut memberikan pengaruh positif sebesar masing-masing $\mathrm{Rp} \mathrm{76,05}$ miliar; Rp 43,94 miliar; Rp 44,81 miliar. Sedangkan berdasarkan komponen Cij pertumbuhan sektor ini bertumbuh relatif lebih lambat dibandingkan dengan sektor sejenis lainnya di provinsi Riau dikarenakan komponen tersebut memberikan pengaruh negatif sebesar Rp 75,18 miliar.

c. Sektor Industri Pengolahan

Berdasarkan komponen Nij, Cij dan Dij pertumbuhan sektor ini bertumbuh relatif lebih cepat dibandingkan dengan sektor sejenis lainnya di provinsi Riau dikarenakan komponen tersebut memberikan pengaruh positif sebesar masing-masing $\mathrm{Rp}$ 159,56 miliar; Rp 4,25 miliar; Rp 163,33 miliar. Sedangkan berdasarkan komponen Mij pertumbuhan sektor ini bertumbuh relatif lebih lambat dibandingkan dengan sektor sejenis lainnya di provinsi Riau dikarenakan komponen tersebut memberikan pengaruh negatif sebesar Rp 0,47 miliar.

d. Sektor Pengadaan Listrik dan Gas

Berdasarkan komponen Nij, Cij dan Dij pertumbuhan sektor ini bertumbuh relatif lebih cepat dibandingkan dengan sektor sejenis lainnya di Provinsi Riau dikarenakan komponen tersebut memberikan pengaruh positif sebesar masing-masing Rp 528,62 juta; Rp 98,41 juta; Rp 158,72 juta. Sedangkan berdasarkan komponen Mij pertumbuhan sektor ini bertumbuh relatif lebih lambat dibandingkan dengan sektor sejenis lainnya di provinsi Riau dikarenakan komponen tersebut memberikan pengaruh negatif sebesar Rp 468,30 juta.

e. Sektor Pengadaan Air, Pengelolaan Sampah, Limbah dan Daur Ulang

Berdasarkan komponen Nij, Cij dan Dij pertumbuhan sektor ini bertumbuh relatif lebih cepat dibandingkan dengan sektor sejenis lainnya di provinsi Riau dikarenakan komponen tersebut memberikan pengaruh positif sebesar masing-masing Rp 684,76 juta; Rp 669,76 juta; Rp 563,28 juta. Sedangkan berdasarkan komponen Mij pertumbuhan sektor ini bertumbuh relatif lebih lambat dibandingkan dengan sektor sejenis lainnya di provinsi Riau dikarenakan komponen tersebut memberikan pengaruh negatif sebesar Rp 191,24 juta. 
Published July 2019

EKONOMIKAWAN : Jurnal Ilmu Ekonomi dan Studi Pembangunan

ISSN : 1693-7600 (Print), ISSN : 2598-0157 (Online), http://jurnal.umsu.ac.Id/index.php/ekawan

\section{f. Sektor Kontruksi}

Berdasarkan komponen Nij, Cij dan Dij pertumbuhan sektor ini bertumbuh relatif lebih cepat dibandingkan dengan sektor sejenis lainnya di provinsi Riau dikarenakan komponen tersebut memberikan pengaruh positif sebesar masing-masing Rp 82,73 miliar; Rp 1,23 miliar; Rp 74,18 miliar. Sedangkan berdasarkan komponen Mij pertumbuhan sektor ini bertumbuh relatif lebih lambat dibandingkan dengan sektor sejenis lainnya di provinsi Riau dikarenakan komponen tersebut memberikan pengaruh negatif sebesar Rp 9,78 miliar.

g. Sektor Perdagangan Besar dan Eceran; Reparasi Mobil dan Sepeda Motor

Berdasarkan komponen Nij, dan Dij pertumbuhan sektor ini bertumbuh relatif lebih cepat dibandingkan dengan sektor sejenis lainnya di provinsi Riau dikarenakan komponen tersebut memberikan pengaruh positif sebesar masing-masing $\mathrm{Rp}$ 188,50 miliar; Rp 173,66 miliar. Sedangkan berdasarkan komponen Mij dan Cij pertumbuhan sektor ini bertumbuh relatif lebih lambat dibandingkan dengan sektor sejenis lainnya di provinsi Riau dikarenakan komponen tersebut memberikan pengaruh negatif sebesar masing-masing Rp 0,44 miliar; Rp 8,40 miliar.

h. Sektor Transportasi dan Pergudangan

Berdasarkan seluruh komponen $\mathrm{Nij}, \mathrm{Mj}$, Cij dan Dij pertumbuhan sektor ini bertumbuh relatif lebih cepat dibandingkan dengan sektor sejenis lainnya di provinsi Riau dikarenakan komponen tersebut memberikan pengaruh positif sebesar masingmasing Rp 15,25 miliar; Rp 2,32 miliar; Rp 3,20 miliar; Rp 20,78 miliar.

i. Sektor Penyediaan Akomodasi dan Makan Minum

Berdasarkan komponen Nij, Mij dan Dij pertumbuhan sektor ini bertumbuh relatif lebih cepat dibandingkan dengan sektor sejenis lainnya di provinsi Riau dikarenakan komponen tersebut memberikan pengaruh positif sebesar masing-masing $\mathrm{Rp}$ 19,57 miliar; Rp 9,11 miliar; Rp 26,16 miliar. Sedangkan berdasarkan komponen Cij pertumbuhan sektor ini bertumbuh relatif lebih lambat dibandingkan dengan sektor sejenis lainnya di provinsi Riau dikarenakan komponen tersebut memberikan pengaruh negatif sebesar Rp 2,52 miliar.

j. Sektor Informasi dan Komunikasi

Berdasarkan seluruh komponen $\mathrm{Nij}, \mathrm{Mj}$, Cij dan Dij pertumbuhan sektor ini bertumbuh relatif lebih cepat dibandingkan dengan sektor sejenis lainnya di provinsi Riau dikarenakan komponen tersebut memberikan pengaruh positif sebesar masingmasing Rp 64,56 miliar; Rp 21,07 miliar; Rp 12,22 miliar; Rp 97,86 miliar.

k. Sektor Jasa Keuangan dan Asuransi

Berdasarkan komponen Nij, Mij dan Dij pertumbuhan sektor ini bertumbuh relatif lebih cepat dibandingkan dengan sektor sejenis lainnya di provinsi Riau dikarenakan komponen tersebut memberikan pengaruh positif sebesar masing-masing $\mathrm{Rp}$ 28,32 miliar; Rp 11,09 miliar; Rp 34,98 miliar. Sedangkan berdasarkan komponen Cij pertumbuhan sektor ini bertumbuh relatif lebih lambat dibandingkan dengan sektor sejenis lainnya di provinsi Riau dikarenakan komponen tersebut memberikan pengaruh negatif sebesar Rp 5,34 miliar. 
Published July 2019

EKONOMIKAWAN : Jurnal Ilmu Ekonomi dan Studi Pembangunan

ISSN : 1693-7600 (Print), ISSN : 2598-0157 (Online), http://jurnal.umsu.ac.Id/index.php/ekawan

\section{Sektor Real Estate}

Berdasarkan seluruh komponen $\mathrm{Nij}, \mathrm{Mj}$, Cij dan Dij pertumbuhan sektor ini bertumbuh relatif lebih cepat dibandingkan dengan sektor sejenis lainnya di provinsi Riau dikarenakan komponen tersebut memberikan pengaruh positif sebesar masingmasing $\mathrm{Rp}$ 23,56 miliar; Rp 0,37 miliar; Rp 1,46 miliar; Rp 25,42 miliar.

m. Sektor Jasa Perusahaan

Berdasarkan komponen Nij, Mij dan Dij pertumbuhan sektor ini bertumbuh relatif lebih cepat dibandingkan dengan sektor sejenis lainnya di provinsi Riau dikarenakan komponen tersebut memberikan pengaruh positif sebesar masing-masing $\mathrm{Rp}$ 2,72 miliar; Rp 0,26 miliar; Rp 2,91 miliar. Sedangkan berdasarkan komponen Cij pertumbuhan sektor ini bertumbuh relatif lebih lambat dibandingkan dengan sektor sejenis lainnya di Provinsi Riau dikarenakan komponen tersebut memberikan pengaruh negatif sebesar Rp 0,07 miliar.

n. Sektor Administrasi Pemerintahan, Pertahanan dan Jaminan Sosial Wajib

Berdasarkan komponen Nij, Cij dan Dij pertumbuhan sektor ini bertumbuh relatif lebih cepat dibandingkan dengan sektor sejenis lainnya di provinsi Riau dikarenakan komponen tersebut memberikan pengaruh positif sebesar masing-masing Rp 51,98 miliar; Rp 2,57 miliar; Rp 36,21 miliar. Sedangkan berdasarkan komponen Mij pertumbuhan sektor ini bertumbuh relatif lebih lambat dibandingkan dengan sektor sejenis lainnya di provinsi Riau dikarenakan komponen tersebut memberikan pengaruh negatif sebesar Rp 18,34 miliar.

o. Sektor Jasa Pendidikan

Berdasarkan komponen Nij, Mij dan Dij pertumbuhan sektor ini bertumbuh relatif lebih cepat dibandingkan dengan sektor sejenis lainnya di Provinsi Riau dikarenakan komponen tersebut memberikan pengaruh positif sebesar masing-masing $\mathrm{Rp}$ 50,44 miliar; Rp 7,58 miliar; Rp 57,40 miliar. Sedangkan berdasarkan komponen Cij pertumbuhan sektor ini bertumbuh relatif lebih lambat dibandingkan dengan sektor sejenis lainnya di provinsi Riau dikarenakan komponen tersebut memberikan pengaruh negatif sebesar Rp 0,62 miliar.

p. Sektor Jasa Kesehatan dan Kegiatan Sosial

Berdasarkan komponen Nij, Cij dan Dij pertumbuhan sektor ini bertumbuh relatif lebih cepat dibandingkan dengan sektor sejenis lainnya di provinsi Riau dikarenakan komponen tersebut memberikan pengaruh positif sebesar masing-masing Rp 9,74 miliar; Rp 0,72 miliar; Rp 10,92 miliar. Sedangkan berdasarkan komponen Mij pertumbuhan sektor ini bertumbuh relatif lebih lambat dibandingkan dengan sektor sejenis lainnya di provinsi Riau dikarenakan komponen tersebut memberikan pengaruh negatif sebesar Rp 157,30 miliar.

q. Sektor Jasa Linnya

Berdasarkan komponen $\mathrm{Nij}$, Cij dan Dij pertumbuhan sektor ini bertumbuh relatif d2 lebih cepat dibandingkan dengan sektor sejenis lainnya di provinsi Riau dikarenakan komponen tersebut memberikan pengaruh positif sebesar masing-masing $\mathrm{Rp}$ 32,03 miliar; Rp 3,41 miliar; Rp 31,56 miliar. Sedangkan berdasarkan komponen Mij pertumbuhan sektor ini bertumbuh relatif lebih lambat dibandingkan dengan sektor sejenis lainnya di provinsi Riau dikarenakan komponen tersebut memberikan pengaruh negatif sebesar Rp 3,88 miliar. 
Published July 2019

EKONOMIKAWAN : Jurnal Ilmu Ekonomi dan Studi Pembangunan

ISSN : 1693-7600 (Print), ISSN : 2598-0157 (Online), http://jurnal.umsu.ac.Id/index.php/ekawan

Tabel 2. Hasil penelitian menggunakan MRP

\begin{tabular}{|c|c|c|c|c|c|}
\hline \multirow{2}{*}{\multicolumn{2}{|c|}{ Lapangan Usaha }} & \multirow{3}{*}{$\begin{array}{c}\text { RPr } \\
0,396\end{array}$} & \multirow{3}{*}{$\begin{array}{c}\text { RPs } \\
1,115\end{array}$} & \multicolumn{2}{|c|}{ Nominal } \\
\hline & & & & $\mathrm{RPr}$ & RPs \\
\hline 1 & $\begin{array}{l}\text { Lapangan Usaha pertanian, } \\
\text { kehutanan dan perikanan }\end{array}$ & & & - & + \\
\hline 2 & $\begin{array}{l}\text { Lapangan Usaha pertambangan dan } \\
\text { penggalian }\end{array}$ & 1,465 & 0,286 & + & - \\
\hline 3 & $\begin{array}{lll}\begin{array}{l}\text { Lapangan } \\
\text { pengolahan }\end{array} & \text { industri } \\
\end{array}$ & 0,768 & 0,833 & - & - \\
\hline 4 & $\begin{array}{l}\text { Lapangan Usaha Pengadaan listrik } \\
\text { dan gas }\end{array}$ & 0,069 & 1,663 & - & + \\
\hline 5 & $\begin{array}{l}\text { Lapangan Usaha pengadaan air, } \\
\text { pengelolaan sampah, limbah dan } \\
\text { daur ulang }\end{array}$ & 0,630 & 0,887 & - & - \\
\hline 6 & Lapangan Usaha kontruksi & 0,700 & 0,804 & - & - \\
\hline 7 & $\begin{array}{l}\text { Lapangan Usaha transportasi dan } \\
\text { pergudangan }\end{array}$ & 0,902 & 0,934 & - & - \\
\hline 8 & $\begin{array}{l}\text { Lapangan Usaha penyediaan } \\
\text { akomodasi dan makan minum }\end{array}$ & 1,191 & 0,722 & + & - \\
\hline 9 & $\begin{array}{l}\text { Lapangan Usaha informasi dan } \\
\text { komunikasi }\end{array}$ & 1,061 & 0,894 & + & - \\
\hline 10 & $\begin{array}{l}\text { Lapangan Usaha jasa keuangan dan } \\
\text { asuransi }\end{array}$ & 1,083 & 0,719 & + & - \\
\hline 11 & Lapangan Usaha real estate & 0,795 & 0,853 & - & - \\
\hline 12 & Lapangan Usaha jasa perusahaan & 0,846 & 0,799 & - & - \\
\hline 13 & $\begin{array}{l}\text { Lapangan Usaha adm perusahaan, } \\
\text { pertahanan dan jaminan sosial wajib }\end{array}$ & 0,580 & 0,862 & - & - \\
\hline 14 & Lapangan Usaha jasa pendidikan & 0,909 & 0,791 & - & - \\
\hline 15 & $\begin{array}{l}\text { Lapangan Usaha jasa kesehatan } \\
\text { dan kegiatan sosial }\end{array}$ & 0,929 & 0,741 & - & - \\
\hline 16 & Lapangan Usaha jasa lainnya & 0,702 & 0,875 & - & - \\
\hline
\end{tabular}

Berdasarkan tabel 2 terdapat beberapa sektor ekonomi yang termasuk ke dalam kategori berikut ini :

a. Jika nilai $R_{T}$ positif (+) dan nilai $R_{S}(+)$ maka sektor tersebut memiliki pertumbuhan yang menonjol baik di tingkat kabupaten Indragiri Hilir maupun di propinsi Riau, dimana kegiatan ini disebut dominan pertumbuhan. Sektor yang termasuk dalam klasifikasi ini tidak ada.

b. Jika nilai $R_{r}$ positif (+) dan nilai $R_{S}(-)$ maka sektor tersebut memiliki pertumbuhan menonjol di propinsi Riau, akan tetapi kurang menonjol di kabupaten Indragiri Hilir . Kegiatan ekonomi yang potesial di kabupaten Indragiri Hilir yaitu sektor yang masuk dalam klasifikasi ini adalah sektor pertambangan dan penggalian; sektor penyediaan akomodasi dan makan minum; sektor informasi dan komunikasi; dan sektor jasa keuangan dan asuransi. 
Published July 2019

EKONOMIKAWAN : Jurnal Ilmu Ekonomi dan Studi Pembangunan

ISSN : $1693-7600$ (Print), ISSN : 2598-0157 (Online), http://jurnal.umsu.ac.Id/index.php/ekawan

c. Jika nilai $R_{r}$ negatif (-) dan nilai $R_{S}$ positif (+) maka sektor tersebut memiliki pertumbuhan menonjol di kabupaten Indragiri Hilir, namun kurang menonjol di tingkat propinsi Riau. Kegiatan ekonomi yang potensial di Kabupaten Indragiri Hilir yaitu sektor yang masuk dalam klasifikasi ini adalah sektor pertanian, kehutanan, dan perikanan serta sektor pengadaan listrik dan gas.

d. Jika nilai $R_{r}$ negatif (-) dan nilai $R_{S}$ negatif (-) maka sektor tersebut memiliki pertumbuhan yang kurang menonjol baik di propinsi Riau maupun kabupaten Indragiri Hilir. Sektor yang masuk dalam klasifikasi ini adalah sektor industri pengolahan; sektor pengadaan air, pengelolaan sampah, limbah dan daur ulang; sektor konstruksi; sektor sektor perdagangan besar dan eceran, reparasi mobil dan sepeda motor; sektor transportasi dan pergudangan; sektor real estate; sektor jasa perusahaan; sektor administrasi pemerintahan, pertahanan, dan jaminan sosial wajib; sektor jasa pendidikan; sektor jasa kesehatan dan kegiatan sosial; serta sektor jasa lainnya.

\section{Hasil Metode Analythical Hierarchy Process (AHP)}

Analisis Hirarki (Analytic Heirarchy Prosess) adalah sebuah hirarki fungsional dengan input utamanya persepsi manusia. Dengan hirarki, suatu masalah kompleks dan tidak terstruktur dipecahkan kedalam kelompok-kelompoknya. Kemudian kelompok tersebut diatur menjadi suatu bentuk hirarki (Brojonegoro 1992).

\section{Pembahasan}

Hasil analisis Location Quotient (LQ) di Kabupaten Indragiri Hilir selama tahun 2012-2016 menunjukkan 9 sektor ekonomi yang teridentifikasi sebagai sektor basis. 9 sektor tersebut antara lain sektor pertanian, kehutanan, dan perikanan; sektor pertambangan dan penggalian; sektor informasi dan komunikasi; sektor jasa keuangan dan asuransi; sektor real estate; sektor administrasi pemerintahan, pertahanan, dan jaminan sosial wajib; sektor jasa pendidikan; sektor kesehatan dan kegiatan sosial; dan sektor jasa lainnya. Kesembilan sektor tersebut telah teridentifikasi memiliki keunggulan komparatif dan lebih dominan jika dibandingkan dengan Propinsi Riau serta dikategorikan sebagai sektor basis ekonomi sehingga mampu memenuhi kebutuhan di Kabupaten Indragiri Hilir ataupun untuk ekspor ke luar daerah.

Analisis Shift Share digunakan untuk menggambarkan kinerja sektor-sektor ekonomi yang ada di Kabupaten Indragiri Hilir yang dibandingkan dengan kinerja perekonomian Propinsi Riau. Perubahan struktur ekonomi dapat disebabkan oleh pertumbuhan ekonomi provinsi atau nasional sebagai referensi yang disebut national growth, pergeseran proporsional atau industrial mix, dan pengaruh keunggulan kompetitif atau regional share.

Analisis MRP atau Model Rasio Pertumbuhan adalah analisis yang digunakan untuk meihat deskripsi kegiatan ekonomi yang potensial terutama struktur ekonomi di Kabupaten Indragiri Hilir dalam perbandingan dengan propinsi Riau. Berdasarkan perhitungan analisis ini tahun 2012-2016, sektor yang potensial di kabupaten Indragiri Hilir yaitu sektor pertanian, kehutanan, dan perikanan serta sektor pengadaan listrik dan gas. Hal ini dapat dilihat dari nilai $R_{T}$ (rasio pertumbuhan wilayah referensi) negatif (-) dan nilai $R_{S}$ (rasio pertumbuhan wilayah studi) positif (+). 
Published July 2019

EKONOMIKAWAN : Jurnal Ilmu Ekonomi dan Studi Pembangunan

ISSN : 1693-7600 (Print), ISSN : 2598-0157 (Online), http://jurnal.umsu.ac.Id/index.php/ekawan

Analytical Hierarchy Process (AHP) merupakan metode yang banyak digunakan pada keputusan untuk banyak kriteria, perencanaan, alokasi sumber daya dan penentuan prioritas dari strategi yang dimiliki pemain dalam situasi konflik. Kebijakan masterplan daerah digunakan untuk merencakan pengembangan sektor unggulan yang ada di Kabupaten Indragiri Hilir . Sektor yang termasuk sektor unggulan adalah sektor pertanian, kehutanan, dan perikanan. Dalam mendukung perencanaan pengembangan sektor unggulan perlu adanya peningkatan kualitas aparat yang terkait. Hal ini dilakukan agar terjadi peningkatan kapasitas dan pemberdayaan SDM yang diarahkan untuk dapat membantu penyusunan kebijakan pengembangan sektor unggulan Kabupaten Indragiri Hilir . Dengan adanya kebijakan masterplan daerah diharapkan dapat menggali potensi sektor unggulan yang ada di Kabupaten Indragiri Hilir supaya dapat dikembangkan dengan maksimal dan dapat mendorong perekonomian Kabupaten Indragiri Hilir ke arah yang lebih baik.

Kebijakan yang dipilih untuk pengembangan sektor unggulan di Kabupaten Indragiri Hilir diharapkan dapat membawa perekonomian daerah dan kesejahteraan di Kabupaten Indragiri Hilir semakin meningkat. Hal ini sesuai dengan salah satu teori pembangunan wilayah yaitu teori pertumbuhan tak berimbang (unballnced growth) yang dikemukakan oleh Hirschman dan Myrdal pada tahun 1958. Pembangunan wilayah pada dasarnya dilakukan dengan menggunakan sumber daya alam secara optimal melalui pengembangan ekonomi lokal yaitu berdasarkan pada kegiatan ekonomi yang terjadi pada suatu wilayah. Teori pertumbuhan tak berimbang memandang bahwa suatu wilayah tidak dapat berkembang apabila ada keseimbangan, sehingga harus terjadi ketidakseimbangan. Artinya, dalam penanaman investasi tidak mungkin dilakukan pada setiap sektor di suatu wiayah secara merata, tetapi harus dilakukan pada sektor-sektor unggulan yang diharapkan dapat menarik kemajuan sektor lainnya.

\section{SIMPULAN}

Sektor-sektor ekonomi yang menjadi sektor unggulan dalam pembangunan perekonomian di Kabupaten Indragiri Hilir adalah sebagai berikut :

1. Hasil analisis Location Quotient (LQ), analisis Shift Share, analisis Model Rasio Pertumbuhan (MRP), dan analisis Overlay menunjukkan bahwa sektor yang menjadi sektor basis (unggulan), sektor yang memiliki keunggulan kompetitif serta memiliki potensi adalah sektor pertanian, kehutanan, dan perikanan.

2. Hasil analisis metode Analytical Hierarchy Process (AHP) menunjukkan strategi kebijakan pengembangan sektor unggulan Kabupaten Indragiri Hilir dengan menggunakan bobot prioritas yang diambil melalui hierarki IV yaitu pada aspek promosi daerah.

\section{DAFTAR PUSTAKA}

Abdullah, Piter dkk. 2002. Daya Saing Daerah : Konsep dan Pengukurannya di Indonesia. Yogyakarta : BPFE.

Agusta, Yudi. 2014. Analytical Hierachy Process (AHP). (Online). Tersedia : https://yudiagusta.wordpress.com/2014/02/23/analytical-hierarchy-process-ahp/.

(Diakses 29 Maret 2018)

Arafandi, A.M. 2015. Teori Pembangunan Wilayah. (Online). Tersedia :

http://ecodevzone.blogspot.co.id/2015/09/teori-pembangunan-wilayah.html. (diakses

Desember 2017). 
BPS. 2015. Kabupaten Indragiri Hilir Dalam Angka 2015. Kabupaten Indragiri Hilir : Badan Pusat Statistik Kabupaten Indragiri Hilir .

BPS. 2016a. Produk Domestik Regional Bruto Kabupaten Indragiri Hilir Menurut Lapangan Usaha 2011-2005. Kabupaten Indragiri Hilir : Badan Pusat Statistik Kabupaten Indragiri Hilir .

BPS. 2017a. Produk Domestik Regional Bruto Kabupaten Indragiri Hilir Menurut Lapangan Usaha 2012-2016. Kabupaten Indragiri Hilir : Badan Pusat Statistik Kabupaten Indragiri Hilir .

BPS. 2017b. Kabupaten Indragiri Hilir Dalam Angka 2017. Kabupaten Indragiri Hilir : Badan Pusat Statistik Kabupaten Indragiri Hilir .

BPS. 2017c. Propinsi Riau Dalam Angka 2017. Propinsi Riau : Badan Pusat Statistik Propinsi Riau.

Brojonegoro, B. 1992. Teori dan Aplikasi Model AHP. Pusat Antar Univesitas, Studi Ekonomi,UI. Jakarta.

Darwanto, Herry. Prinsip Dasar Pembangunan Ekonomi Daerah. (Online). Tersedia :

https://www.academia.edu/8394963/Prinsip_Dasar_Pembangunan_Ekonomi_Daerah. (diakses 07 Desember 2017).

Hamali, Sambudi. 2015. Pengambilan Keputusan Manajemen Menggunakan Analytical Hierarchy Process (AHP). (Online). Tersedia http://sbm.binus.ac.id/2015/05/25/pengambilan-keputusan-manajemen-mengunakananalytical-hierarchy-process-ahp/. (Diakses 29 Maret 2018)

Kurnianto, Adi. 2014. Teori-Teori Pembangunan Ekonomi. (Online). Tersedia : https://superkurnia.wordpress.com/2014/09/08/teori-teori-pembangunan-ekonomi/. (diakses 11 Januari 2018).

Kusbiantoro, Danang. 2012. Analisis Perubahan Struktur Ekonomi dan Identifikasi Sektor Unggulan di Kabupaten Ngawi Tahun 2002-2010. Skripsi. Ekonomi Pembangunan, Universitas Sebelas Maret.

Lestari, A.A.P. 2017. Peranan Sektor Basis Terhadap Peningkatan Pendapatan Asli Daerah (PAD) Kabupaten Sarolangun. Universitas Jambi : Vol 6 No 1 (2017): Jurnal Manajemen Terapan dan Keuangan.

Mubarrok, Wafiyulloh. 2016. Analisis Pembangunan Wilayah Berbasiis Sektor Unggulan dan Strategi Pengembangannya : Studi Kasus Kabupaten Ogan Komering Ulu Tahun 2010-2014. Universitas Muhammadiyah Yogyakarta : Jurnal Ekonomi.

Novrilasari, Dylla. 2008. Analisis Sektorr Unggulan Dalam Meningkatkan Perekonomian dan Pembangunan Wilayah Kabupaten Kuantan Singingi. Skripsi. Ekonomi Pertanian dan Sumber Daya, Institur Pertanian Bogor.

Nugroho, Iwan dan Rokhmin Dahuri. 2004. Pembangunan Wilayah: Perspektif Ekonomi, Sosial, dan Lingkungan. Jakarta : LP3ES.

Pakmono. Pengertian Pembangunan Ekonomi dan Tujuan Pembangunan Ekonomi. (Online). Tersedia :

http://www.pakmono.com/2015/01/pengertian-pembangunan-ekonomi-dan.html (diakses 12 Oktober 2017).

Republik Indonesia. 1999. Undang-Undang No. 22 Tahun 1999 tentang Pemerintah Daerah. Lembaran Negara RI Tahun 1999, No. 60. Sekretariat Negara. Jakarta. 
EKONOMIKAWAN : Jurnal Ilmu Ekonomi dan Studi Pembangunan

ISSN : $1693-7600$ (Print), ISSN : 2598-0157 (Online), http://jurnal.umsu.ac.ld/index.php/ekawan

Republik Indonesia. 2000. Peraturan Pemerintah Republik Indonesia Nomor 84 Tahun 2000 Tentang Pedoman Organisasi Perangkat Daerah. Lembaran Negara RI Tahun 2000, No. 165. Sekretaris Negara. Jakarta.

Saaty, L. 1991.Pengambilan Keputusan bagi para Pemimpin, Proses Hirarki Analitik untuk Pengambilan Keputusan dalam Situasi yang Kompleks. Jakarta:PT. Pustaka Binaman Pressindo.

Setiyanto, Adi, dan Bambang Irawan. Tanpa Tahun. Pembangunan Berbasis Wilayah : Dasar Teori, Konsep Operasioal, dan Implementasinya Di Sektor Pertanian. (Online). Tersedia : http://www.litbang.pertanian. go.id/

buku/ekoregion/Bab-II-4.pdf. (diakses 07 Desember 2017).

Syaiful, Rifan. 2013. Mengenal Metode AHP (Disertai studi kasus : Pemilihan Mahasiswa Terbaik). (Online). Tersedia : http://funpreuner.blogspot.co.id/2012/02/mengenalmetode-ahp-disertai-studi.html. (Diakses 28 Maret 2018)

Tantowirico. 2013. Teori Pertumbuhan dan Pembangunan Ekonomi. (Online). Tersedia : https://gerilyastatistik.wordpress.com/2013/01/24/teori-pertumbuhan-danpembangunan-ekonomi/. (diakses 11 Januari 2018).

Tarigan, Robinson. 2004. Ekonomi Regional Teori dan Aplikasi. Jakarta : Bumi Aksara.

Yudi. 2015. Sistem Pendukung Keputusan Pemilihan Perumahan Methode AHP Dan GIS Statis Kota Medan Sebagai Salah Satu Kriteria Pemilihan. Universitas Potensi Utama : Jurnal Eksplora Informatika Vol. 5, No. 1.

Yusuf, Maulana. 1999. Model Rasio Pertumbuhan (MRP) Sebagai Salah Satu Alat Analisis Alternatif Dalam Perencanaan Wilayah dan Kota Aplikasi Model : Wilayah BangkaBelitung. Ekonomi dan Keuangan Indonesia Volume XLVII Nomor 2, halaman 219 - 233. 